\title{
The Effect of Different Freezing Rates on Fertilizing Ability of Frozen-Thawed Chicken Spermatozoa
}

\author{
Noboru Fujihara and Roger B. BuCKI.AND* \\ Department of Animal Science, Kyushu University, \\ Hakozaki, Fukuoka 812 Japan \\ *Department of Animal Science, Macdonald College of \\ McGill University, Ste. Anne de Bellevue, \\ P.Q., Canada H9X $1 \mathrm{CO}$
}

(Accepted for publication October 6, 1986)

\begin{abstract}
Summary. The effect of two different freezing velocities $\left(1{ }^{\circ} \mathrm{C} / \mathrm{min}\right.$ and $\left.6{ }^{\circ} \mathrm{C} / \mathrm{min}\right)$ on fertilizing ability of spermatozoa from the roosters selected for high fertility with frozen-thawed spermatozoa and the randomly selected control males was determined. Significantly $(\mathrm{P}<0.05)$ higher fertility was obtained when semen of the selected male was frozen at a rate of $1^{\circ} \mathrm{C} / \mathrm{min}$ to $-70^{\circ} \mathrm{C}$. In contrast, semen frozen at $6^{\circ} \mathrm{C} / \mathrm{min}$ until $-70^{\circ} \mathrm{C}$ showed no significant difference in fertility between two male lines. The results of the present study indicate the possibility of male selection for higher freezability of spermatozoa. Better viability and fertilizing capacity of frozen-thawed fowl spermatozoa were suggested to be obtained with a freezing rate of $1^{\circ} \mathrm{C} / \mathrm{min}$. KEY WORDS; CHICKEN, SPERMATOZOA, FREEZING, FERTILITY.
\end{abstract}

Jpn J Anim Reprod 33, 11-14, 1987

Efforts to freeze chicken semen have been relatively successful, but the fertility of frozenthawed semen after single insemination remains lower (Watanabe, 1967; Mitchel et al., 1977; Lake and Stewart, 1978) as compared with that of bull semen. Recently, Lake et al. (1981) and Lake and Ravie (1984) has obtained considerably higher fertility with freeze-thaw rooster sperm, inseminating at a 3-day interval or three consecutive days. Lake and Stewart (1978) suggested the possibility of genetic difference between male chicken with regard to freezability of spermatozoa. Scott et al. (1978) reported a significant difference in fertility of spermatozoa between males of fourth generation selected for duration of fertility with frozen semen and randomly selected males. Sexton et al. (1978) also obtained the results showing the highest fertility with semen from the male with higher sperm freezability. These results indicate that genetic parameters associated with viability and fertility of frozen-thawed rooster semen may be different.
On the other hand, cooling velocity of semen at a rate of $1^{\circ} \mathrm{C} / \mathrm{min}$ to $-35^{\circ} \mathrm{C}$ was successful for better viability of freeze-thaw turkey spermatozoa (Marqez and Ogasawara, 1977; Sharp et al., 1982). However, no fertility study has yet been conducted to establish optimal rate of freezing for spermatozoa from different male birds.

This experiment was carried out to determine the effect of different freezing velocity on fertilizing capacity of spermatozoa of the cockerels of high fertility with freeze-thaw spermatozoa and the randomly selected males.

\section{Materials and Methods}

A total of 20 males of a line (generation 4) of chicken selected for duration of fertility of frozen-thawed semen and 20 males of the randomly selected control line were used in this study (Scott et al., 1978). Pooled semen samples were collected from each male group, diluted 1 to 3 with Lake's solution containing $13.64 \%$ 
Table 1. Experimental procedures

\begin{tabular}{|c|c|c|c|c|c|c|}
\hline \multirow{2}{*}{ Group } & \multicolumn{2}{|c|}{ Male line } & \multicolumn{2}{|c|}{ Apparatus } & \multicolumn{2}{|c|}{ Freezing rate } \\
\hline & Selected & Control & Cryocool-100 & Macdonald Apparatus & $1^{\circ} \mathrm{C} / \mathrm{min}$ & $6^{\circ} \mathrm{C} / \mathrm{min}$ \\
\hline 1 & & 0 & 0 & & 0 & \\
\hline 2 & 0 & & 0 & & $\bigcirc$ & \\
\hline 3 & & 0 & & & 0 & \\
\hline 4 & 0 & & & & $\bigcirc$ & \\
\hline 5 & & 0 & & & & 0 \\
\hline 6 & 0 & & & $\Omega$ & & 0 \\
\hline
\end{tabular}

of glycerol (Lake, 1968) and packaged in a $0.5 \mathrm{ml}$ plastic straw. Semen samples were kept in an iced-water bath $\left(0-3^{\circ} \mathrm{C}\right)$ until frozen. Two different apparatuses and two methods of freezing were employed for each semen group (Table 1). Same samples were frozen with either Cryocool-100 (Cryocool, Ontario, Canada) or Macdonald College Freeze Thaw Apparatus (Mitchell et al., 1975) at freezing speed of $1^{\circ} \mathrm{C}$ or $6^{\circ} \mathrm{C} / \mathrm{min}$ until $-70^{\circ} \mathrm{C}$, followed by plunging the straws directly into liquid nitrogen $\left(-196^{\circ} \mathrm{C}\right)$. When semen temperature reached $-196^{\circ} \mathrm{C}$, the straws were taken out, placed in an iced-water bath and deglycerolized by the method of Mitchell et al. (1977). Following deglycerolization, spermatozoa were resuspended in Lake's deglycerolizing fluid (Lake, 1968) to produce approximately $1-3 \times 10^{9}$ cells $/ \mathrm{m} l$ of semen. Sperm motility was scored immediately after thawing of frozen semen according to the method of Wheeler and Andrews (1943).

Ninety-six White Leghorn hens were divided into six groups and inseminated with semen of each experimental group. All hens were inseminated intravaginally by depositing semen into the posterior site of the vagina. Eggs were saved for 7 days, starting 2 days after insemination, incubated, and candled at 5 days of incubation. Percent fertilizity up to day 7 after insemination was measured. Percent data were transformed to arcsin and all data were subjected to statistical analysis using analysis of variance followed by the $t$-test for comparing difference between the groups (Steel and Torrie, 1980).

\section{Results and Discussion}

As shown in Table 1, fertility measured in this study was slightly lower than that previously reported (Mitchell et al., 1977; Lake and Stewart, 1978; Sexton et al., 1978). Lower fertility obtained here may be due partly to the amount of glycerol that remained after processing or the depth of insemination site. However, significant differences were observed between the male lines and freezing velocities (Table 2). The highest fertility was obtained when semen of the selected male was frozen at $1{ }^{\circ} \mathrm{C} / \mathrm{min}$ to $-70^{\circ} \mathrm{C}$ using Cryocool-100 apparatus, the result being statistically significant $(P<0.05)$. No significant difrence in fertility was found between Cryocool-100 and Macdonald Apparatus when semen from males in the high group was cooled at a rate of $1^{\circ} \mathrm{C} / \mathrm{min}$. When semen from the selected males was frozen at $6^{\circ}, \mathrm{C}$ min with Macdonald Apparatus, fertility was significantly $(P<0.05)$ poor as compared with that of obtained using Cryocool-100 at $1^{\circ} \mathrm{C} / \mathrm{min}$.

Semen from the control males showed lower fertility in any experimental condition (Table 2). Semen cooled at $6^{\circ} \mathrm{C} / \mathrm{min}$ with Macdonald Apparatus, fertility was significantly $(\mathrm{P}<0.05)$ betwmeen two male lines. Scott et al. (1978) reported a significant difference in fertility duration between the selected and control males when semen was frozen at $6^{\circ} \mathrm{C} / \mathrm{min}$ to $-196^{\circ} \mathrm{C}$. Such a difference in fertility rate with the same method as described by Mitchel et al. (1977) is due probably to the difference of the remaining amount of glycerol after processing and/or 
Table 2. Viability and fertilizing capacity of spermatozoa from males selected for high fertility with frozen-thawed sperm and randomly selected males

\begin{tabular}{cccccc}
\hline Group & $\begin{array}{c}\text { Ne. of hens } \\
\text { used }\end{array}$ & $\begin{array}{c}\text { Sperm motility } \\
\text { score }\end{array}$ & $\begin{array}{c}\text { No. of sperm } \\
\text { inseminated }\end{array}$ & Egg production & Fertility \\
\hline & & & $\left(\times 10^{6}\right.$ cells $)$ & $(\%)$ & $(\%)$ \\
1 & 21 & $4.01 \pm 0.31^{\mathrm{ab} *}$ & 100 & $69.69 \pm 11.95$ & $3.69 \pm 4.90^{\mathrm{b} *}$ \\
3 & 23 & $4.28 \pm 0.32^{\mathrm{a}}$ & 100 & $71.21 \pm 12.25$ & $17.70 \pm 10.28^{\mathrm{a}}$ \\
4 & 11 & $3.75 \pm 0.33^{\mathrm{bc}}$ & 100 & $67.51 \pm 14.74$ & $1.47 \pm 1.98^{\mathrm{b}}$ \\
5 & 12 & $4.25 \pm 0.31^{\mathrm{a}}$ & 100 & $67.74 \pm 16.10$ & $6.75 \pm 6.92^{\mathrm{ab}}$ \\
6 & 12 & $3.43 \pm 0.35^{\mathrm{c}}$ & 100 & $69.70 \pm 11.60$ & $1.68 \pm 2.22^{\mathrm{b}}$ \\
\hline
\end{tabular}

* Mean \pm standard deviation. Means with different superscripts are significantly different $(\mathrm{P}<0.05)$.

the depth of insemination site. With poultry semen, best results can be achieved when chicken semen is cooled through the transition phase $\left(-5\right.$ to $\left.-15^{\circ} \mathrm{C}\right)$ at a slow cooling rate $(1$ to $\left.8^{\circ} \mathrm{C} / \mathrm{min}\right)$ to some temperature below $-15^{\circ} \mathrm{C}$ before storage at $-196^{\circ} \mathrm{C}$ (Sexton, 1979). On the other hand, thawing temperature also affects post-thaw motility and fertilizing capacity of frozen poultry semen (Sexton, 1979; Watanabe et al., 1968).

Recently, data have been shown with bull semen to indicate that factors such as freeze rate, thaw rate, and level of cryoprotectant interact, and an optimal combination of these variables is needed for satisfactory results (Robbins et al., 1972). However, rate of freezing can exert marked effects on sperm survival (Pickett et al., 1976), and slower cooling has also been associated with greater post-thaw motility for spermatozoa frozen either in ampules or in straws (Mcfee and Swanson, 1960; Martin, 1965; Ennen et al., 1976). These valuable parameters, which have been established in bull semen, remain to be solved for freezing fowl semen.

Sperm activity after freeze-thaw process was inclined to be higher when semen was cooled at $1^{\circ} \mathrm{C} / \mathrm{min}$ using both equipments though the results were not significant. These results postulate the slower cooling rate $\left(1^{\circ} \mathrm{C} / \mathrm{min}\right)$ for better viability of freeze-thaw spermatozoa. In the present study, better fertility was directly proportional to higher sperm motility $(r=0.755)$.

The results of the present experiment show that the male can be selected for higher freezability of sperm and that freezing velocity at
$1{ }^{\circ} \mathrm{C} /$ min may be successful for better viability and fertilizing capacity of frozen-thawed fowl spermatozoa.

\section{References}

Ennen BD, Berndtson WE, Mortimer RG, Pickett BW (1976) A simple controlled rate freezing apparatus as applied to freezing poultry semen. Poultry Sci 54: 1796. (abstract)

Mitchell RL, Buckland RB, Kennedy BW (1977) Heritability of fertility of frozen and fresh chicken semen and the relationship between the fertility of frozen and fresh semen. Poultry Sci 56: 1168-1177.

Pickett BW, Berndtson WE, Sullivan, JJ (1976) Techniques for processing and packaging bovine semen. Proc VI Tech Conf Artif Insem Reprod. NAAB: $34-35$.

Robbins RK, Gerber LE, Saacke, RG (1972) Influence of thaw rate on maintenance of the acrosomal cap. J Anim Sci 35: 253 (abstract).

Scott R, Ansah G, Buckland RB, Kennedy BW (1978) Four generation of selection for fertility of frozen chicken semen. Piultry Sci 57: 1161 (abstract).

Sexton TJ, Buckland RB, Lopez R (1978) Comparison of two procedures for freezing semen from cocks of high and low fertility with frozen semen. Poultry Sci 57: 550-552.

Sexton TJ (1979) Preservation of poultry semen. In: Animal Reproduction (Hawk HW ed.), John Wiley \& Sons, New York.

Sharp J, Tai JL, Fuqua L, Ogasawara FX (1982) Comparisons of slow freezing $\left(1^{\circ} \mathrm{C} / \mathrm{min}\right)$ and two step freezing with turkey semen. Poultry Sci 61: 1542 (abstract).

Steel RGD, Torrie JH (1980) Principles and Procedures of Statistics: A Biometrical Approach. McGraw-Hill, New Effect of processing procedures on motility of bovine spermatozoa frozen 
in $.25 \mathrm{ml}$ straws. J Anim Sci 43: 651-656.

Lake PE (1968) Observation on freezing fowl spermatozoa in liquid nitrogen. VI. Cong Stern Reprod Anim Insem Artif., Paris, Vol. II: 16331635.

Lake PE, Stewart JM (1978) Preservation of fowl semen in liquid nitrogen-an improved method. Br Poultry Sci 19: 187-194.

Lake PE, Ravie O, Macdam J (1981) Preservation of fowl semen in liquid nitrogen: Application to breeding programmes. $\mathrm{Br}$ Poultry Sci 22: 71-77.

Lake PE, Ravie O (1984) An exploration of cryoprotective compounds for fowl spermatozoa. $\mathrm{Br}$ Poultry Sci 25: 145-150.

Marquez BJ, Ogsawara FX (1977) Ultrastructural changes in turkey spermatozoa after immersion in glycerolyed media and during various steps used for cryopreservation. Poultry Sci 56: 18061813.

Martin ICA (1965) Effects of rate of cooling to $5^{\circ} \mathrm{C}$, storage at $5^{\circ} \mathrm{C}$, glycerol concentration, sodium chloride, fructose and glycine on the revival of deep-frozen bull spermatozoa. J Agric Sci 64: $425-432$.

Mcfee AF, Swanson EW (1960) The influence of cooling rates and storage temperatures on sperm activity. Artif Insem Dig 8: 12-15.

Mitchell RL, Buckland RB, Forgrave L, Baker RD (1975) York. pp. 67-238.

Watanabe M (1967) Studies on deep-freezing preservation of chicken semen. J Fac Fish Anim Husb Hiroshima Univ 7: 9-23.

Watanabe M, Irie K, Sakabe T, Takahashi T (1968) Studies on deep freezing preservation of fowl semen. I. Relationship between the deep freezing time and motility of fowl spermatozoa in deep freezing preservation by Liquid Nitrogen. Japan Poultry Sci 5: 198-201.

Wheeler NC, Andrews FN (1943) Seasonal variation in semen production in the domestic fowl. Poultry Sci 22: 361-367.

\title{
鶏精液の凍轺速度が精子の受精能力に及ぼす影響
}

\author{
藤原昇 - Roger B. BUCKLAND* \\ 九州大学農学部, *マッギール大学農学部
}

\begin{abstract}
精子の耐凍性を指標に選抜した雄鶏および通常の雄鶏
方, $6^{\circ} \mathrm{C} /$ 分の速度で冷却した坳合には, 二つの雄鷂精液 から採取した精液を, $-70^{\circ} \mathrm{C}$ まで $1^{\circ} \mathrm{C} /$ 分ならびに $6^{\circ} \mathrm{C} /$ 間に受精率の差は認められなかった。

これらの結果から，精子の耐凍性を指標にして雄鷄を 分の冷却速度で涷結した場合の精子の受精能力を比校検 選拢するととができるとと，また鶏精液の涷結の際は， まで涷結した場合に，最も高い受精率が得られた。一 冷却速度は $1^{\circ} \mathrm{C} /$ 分が適正であるととが推定された。
\end{abstract}

